International Journal of Heritage, Tourism and Hospitality Vol. (11), No. (1/2), March, 2017

By: Faculty of Tourism and Hotels, Fayoum University

\title{
Menu Sustainability in the Egyptian Upscale and Fine Dinning Restaurants: Descriptive Approach
}

Hesham Ezzat Saad Alaa Ashry Raslan

Faculty of Tourism and Hotels, Fayoum University

\section{Abstract}

Sustainability is considered as one of the most important issues in food trends over the globe. Research about menu sustainability still needs more empirical investigations. This research aims to explore if restaurateurs in Egypt are adapting principles and practices of sustainability in constructing their restaurant's menus. The current research adopted a deductive approach using the questionnaire strategy as a data collection instrument. The population of the study was the general managers and assistant general managers who are working in the upscale and fine dining restaurants in Greater Cairo (Cairo and Giza). Simple random sampling was chosen as the most proper sampling technique to achieve the study objectives. 300 questionnaires were distributed to managers of the sampled restaurants. The returned and valid questionnaires for analysis were 284 , with a valid response rate estimated to be $94.3 \%$. Research findings highlighted that the investigated restaurants responded effectively to the growing needs of the consumers who become more concerned with environmental friendly and sustainable products and services. Key words: Menu sustainability, Dinning Restaurants, Egyptian Upscale restaurants.

\section{Introduction}

Hospitality faced with many challenges, as this industry has displayed an almost constant growth since the 1950s. Characterized by globalization, which increases the number of competitors (Bukhari et al., 2000; Webster, 2004; Line \& Runyan, 2012), as well as climate disasters and armed conflicts (Raymond, 2016). Also, it must meet consumer expectations that are constantly evolving with regard to quality of service and respond to the increasing environmental and social awareness of customer (Wilkins et al., 2007).Now, more and more hotels and restaurants are becoming more sustainable as they embark on a wide range of measures designed to reduce their impact on the environment (Chou et al., 2012). Around 80\% of European hoteliers are involved in some kind of activity oriented toward the environment ; areas most concerned are: Energy saving measures, water saving procedures, green products purchasing, and waste minimization practices (Zhang et al., 2012).Hospitality management associations are paying increased attention to providing the industry with best practice examples and guidelines. An example is the International Tourism Partnership, which has produced a set of sustainable hotel sittings, design and construction principles(Enz and Siguaw, 1999).Another example for the restaurant industry is the American National Restaurant Association which has established a set of guidelines that move the restaurant industry toward more environmentally sound practices and sustainable initiatives(Wilkins et al., 2007).

Kasimu (2012) argued that the International Hotel \& Restaurant Association (IH \&RA) recently realized the need for more sustainable practices and has developed a set of ecological, business smart solutions. Practices they promote include energy, water and other natural resource conservation, increasing recycling and encouraging the use of sustainable materials and alternative energy sources. Business \& the Environment (2008) and Sloan et al. (2013) indicated that the Green Restaurant Association (GRA), a US non-profit organization, with the mission of creating an ecologically sustainable restaurant industry, established several environmental guidelines for restaurants and promoted examples of best practices to facilitate achieving environmental sustainability. An example was its 'Guide of Endorsed Products', a list of environmentally responsible products for the restaurant industry which provide information 
about organically certified, recycled, chlorine free and other environmentally preferable product choices.

Previous studies pointed out that currently, customers are more knowledgeable, experienced, and aware of the effect of the food type on their health status and also the nutrition pattern on the environment. They want more healthful and nutritional food that are low in fat and calories. Consumers are also more likely to seek hospitality services that have adopted sustainable practices and interested of the sources and production process of the food they are eating (Dodds and Joppe,2005;Willard, 2005;Sloan et al., 2009;Solomon et al., 2010;Trivette, 2012). Constructing a sustainable menu for restaurants are not only is an environmentally demand, but also it's the customers' expectations, and a vital element in selecting specific places or products (Willard, 2005; Sloan, 2009). Despite its viable significance, there are limited studies that have investigated the issue of menu sustainability in the Egyptian food service sector, So the aim of this study is to explore if fine dining restaurants in Egypt are adopting sustainability principles and practices in their menus.

\section{Review of literature}

Review of literature showed that there is no single established definition of sustainable food; the concept is still unclear due to its many practices as highlighted by Sloan et al. (2009). Sustainable food is defined as a way of producing and consuming food that ultimately promotes the continuous well-being of ourselves and our planet (SUSTAIN, 2009).The Sustainable Development Commission (SDC), in UK, defined food sustainability as:

- Providing customers with safe, vigorous and nutritive food and can meet the requirements of the people who have less money.

- Provides a viable livelihood for farmers, processors and retailers, whose employees enjoy a safe and hygienic working environment.

- Respects biophysical and environmental limits in its production and processing, while reducing energy consumption and improving the environment; it also respects the highest standards of animal health and welfare, compatible with the production of affordable food for all sectors of society.

- Supports rural economies and the diversity of rural culture, by depending on local suppliers that decrease distance between food grown and consumed (Sloan et al., 2013).

Because of its nature, the sustainable food is considered more expensive than other kinds of food. Restaurant operators who are looking for to offer clients with sustainable food items may be forced to increase their menu prices. There is a proof from previous research that restaurant customers are willing to pay an extra charges or price for having sustainable food choices (Choiand Parsa, 2009; Schubert et al., 2010; Trip Advisor, 2010; Albin, 2012; Namkung\&Jang, 2017). Many researches have studied customers attitudes toward sustainable food, and they assured that there are growing awareness among customers of the importance of sustainability, it is also consider a vital in customers choosing to buy or visit a specific restaurant (Choi and Parsa, 2006; Manaktola and Jauhari, 2007; Dutta et al., 2008). Results from prior studies mentioned the restaurants that are considered sustainable and provide organic, vegan or healthy food, may have outstanding success (Enz and Siguaw, 1999; Goodman, 2000; Nielsen, 2004; Bohdanowicz, 2005; Schubert et al., 2010, Sloan et al., 2013).

The concept of Unsustainable food may be clear for most customers. Customers are seeing the word 'organic' on the food label; realize what organic food definition (Constance \& Choi, 2010). In the same way, 'Fair-trade' food is recognized, defined and certainly marked by its sticky label 
(Food Standards Agency -Fair-trade, 2015). On the contrary because of the wide of important principles related with sustainable food such as environmentally friendly, well-being, and community issues, it seems too difficult to develop a label for sustainable food. The main effects of several of the products delivered to hospitality premises may extend to the producing raw materials, processing, packing and distribution (Van Rheede \& Blomme, 2012).

There are a range of principles and practices which can contribute to create a sustainable menu. Sourcing ingredients from local farmers and suppliers is considered an important principle (Vieregge et al., 2007; Weber \&Matthews, 2008; Schubert et al., 2010). It helps to; decrease the environmental influence resulting from transporting food and also support the local economy. The 'localvore' is a movement, which encourages participants to consume only locally produced food. However, it can be easy to conceive that this practice is more energy resourceful than transported products (Vermeir and Verbeke, 2006; DeWeerdt, 2015). The 'food miles' or, the 'food transportation' is primarily concerned with costs related to the environmental and social and associated with food transport, from where it is grown, harvested, purchased, processed, and delivered to the end users or consumers. Supporting this view, Schneider and Francis (2006) conducted a study to identify the motives of consuming local food, the results showed that the environmental and health concerns were the most important motives behind consuming local food. Currently, The farm-gate prices in developed countries have been reduced due to the vast decrease in transportation costs, inexpensive food manufacture in developing countries, in addition, the increase of huge food businesses and superstore chains (Brown and Miller, 2008; Rose et al.,2008; DiPietro \&Campbell, 2014). Unfortunately, this leads to disappearing of local shops or outlets and damaging rural economies and agriculture societies (Leviten-Reid and Zepeda, 2004; Seyfang, 2006).

Organic food is another vital principle, food that slicked label as organic is produced in deeply controlled farming systems in which means are used that emanate from the environment at all stages. Organic agriculture includes all agricultural systems that promote environmentally, socially and economically sustainable food production, and these systems are considered to be an essential component of the success of production. Organic agriculture greatly reduces synthetic inputs such as; industrial fertilizers, synthetic pesticides, veterinary drugs, seeds and genetically modified strains, preservatives, additives, and irradiation (Pollan, 2001). Now, there are diverse sticky labels for organic food, this may cause confusion for customers especially who are not familiar with agricultural and production issues. It is important to improve the nutritious quality of food. Poor nutrient foods and poor food selections can mainly clarify the widespread of obesity and diabetes problems in the western countries. Traditional agricultural methods that increasingly utilize chemical fertilizers and pesticides are chiefly responsible for such great nutrient damage, while past research stated that organic food foodstuffs have higher of valuable nutrients (McCullum, 2004; Magnusson, 2008).

Serving seasonal food is essential in constructing sustainable menu. According to Sloan et al. (2013), menus should include fresh seasonal items and the restaurants' chefs should exploit the flow fresh foodstuffs seasons that are existing. Using seasonal food will decrease the transportation activities and food miles and improve local and provincial community as well as often leading to a renewal of local cooking customs and traditions (Business \& the Environment, 2008). Consuming plant based food such as vegetables and fruits are also important for health and environment. For health, it cuts down the mount of saturated fat intake and increases fiber intake and avoids diseases. For environment concerns, it conserves resource consumption, beef is energy intensive, and producing one kilo of meats needs seven kilos of grain (Horrigan et al., 
2002). Findings consistent with that, a study conducted by Marlow (2009) suggested that we should decrease the amount of meat consumption and depend mainly on grass feeding not grain. Menu sustainability also requires a Fair-trade food. Fair-trade has sought to achieve better prices, decent working conditions and fair trade conditions for local farmers and workers especially small- scale to sell and market their goods and products at "close" prices of world prices and to reduce their exploitation. It also seeks to support the development of agricultural communities to enable them to determine their future and protect the environment in which they live and work. Globally, the market share of fair-trade products only accounts for about $2 \%$. Products with the 'Fair-trade' label assurance firm principles global on certain environmentally friendly and workers compensation aspects (Food Standards Agency -Fair-trade, 2015).Egypt Fair-trade Organization, (EFO) was established in 1998, is the first fair trade certified manufacturer that aims to supporting the cultural, social and environmentally fair trade principles and empowering local communities by offering poor handicrafts worker with support service, e.g. marketing and training. The scope of the EFO is only selling Egyptian handmade crafts (EFO, 2017).

Assured food is compatible with food safety and traceability, animal welfare, environmental protection. The world standard Global Gap and the EurepGAP standard in Europe are aimed to help manufacturers in improving food quality and safety, biodiversity, using natural resources efficiently, minimizing of pesticides and fertilizers usage. There are many examples of signs are used around the world; the red tractor sign in the United Kingdom, 'Stop- Climate-Change' (SCC), in Germany, aimed to be 'climate neutral'. The aim of these national standards is to make customers sure that the food labeled "organic foods" they purchase are grown, produced, processed and certified according to the national organic standards (McMichael et al., 2007; Weber \& Matthews, 2008; Herrero et al., 2010)

\section{Research methods}

The population of this study consisted of the general managers and assistant general managers of upscale and fine dining restaurants in Greater Cairo. Upscale and fine dining restaurants were chosen for many reasons. Firstly, they are considered full service operations with high check average; they target high level of income, education and social market segment. Secondly, the high pricing is one of the most important elements that characterized sustainable food consumption. As the customers value health, environment, social fair, animal welfare and wellbeing of the society and they are willing to pay a premium price for sustainable products and services. According to Chamber of Tourist Establishments guide (ETC, 2015), there are 215 upscale and fine dining restaurants (stand-alone and within lodging establishments) in Greater Cairo containing about 450 mangers at all based on the information provided by the restaurants managements. The researchers contacted the managements of the 215 restaurants mentioned to explain the aim of the study and obtain permission for data collection.

A simple random sample was used for the participants as the population is homogeneous, with each individual having the same probability of being selected. A sample 300 individuals with a percentage exceeds 10 is acceptable as recommended by Gay \& Diehl (1992). A quantitative approach was adopted to achieve the study objectives; the study has developed structured questionnaire as the result of the literature review (Leviten-Reid \& Zepeda, 2004;SUSTAIN, 2009; Herrero et al., 2010;Albin, 2012; Halperin, 2013;Sloan et al., 2013;Laggan, 2015; Durbin, 2016;Raymond, 2016, Munjal et al., 2016). The instrument was piloted on30 of the respondents to validate the constructs of the study. The purpose of the pilot study was to refine the questionnaire and identify any potential problems. As a result, ambiguity and unclear words have 
been eliminated from the questionnaire. The final questionnaire consisted of two sections. The first section is the demographic data which included gender, age, occupation, education, and experience. The second section consisted of 33 statements covered 7 principles of menu sustainability, these principles were; management commitment to constructing sustainable menu (included seven statements), staff awareness of menu sustainability (included four statements), dependence on local source, seasonal and organic ingredients (included seven statements), providing balanced, healthy and nutritious meals (included seven statements), free of waste (included two statements), grow some ingredients (included four statements), choose fair-trade products (included two statements). The respondents were asked to indicate their agreement of the statements on a five points of Likert- type scales, which range from $5=$ strongly agree to $1=$ strongly disagree. 300 questionnaires were distributed to the selected sample, 16 were excluded because of missing data and 284 were analyzed.

\section{Results and discussions}

The following sections present the response of the mangers. Table (1) summarizes the demographic profile of the respondents. Amongst the respondents, $100 \%$ were male, none of them were female. Also, more than $90 \%$ of them have a bachelor degree, whilst approximately $10 \%$ are with postgraduate university qualification. As for the experience in current position, more than half (50.4\%) have been working in their current position for 2-6 years. Nearly, 20\% of the managers have worked for 6-10 years. About 30\% of the respondents have worked in their positions for more than 10 years. Regarding the age, more than half of the responding managers (65\%) were 40 to 50 years old at the time of the survey, $20 \%$ in the age group 30-40; and about $10 \%$ were in the age group 50-60. Just about $5 \%$ of the managers were less than 30 years old.

Table1. Demographic profile of the respondents $(n=284)$

\begin{tabular}{|c|c|c|c|}
\hline \multirow{2}{*}{ Gender } & & Frequency & Percent (\%) \\
\cline { 2 - 4 } & Male & 284 & $100 \%$ \\
\hline \multirow{2}{*}{ Position } & Female & -- & -- \\
\cline { 2 - 4 } & General manager & 120 & 42.3 \\
\cline { 2 - 4 } & Assistant General Manager & 164 & 57.7 \\
\cline { 2 - 4 } & Under 30 & 14 & 4.9 \\
\cline { 2 - 4 } & $30-40$ & 57 & 20.1 \\
\cline { 2 - 4 } & $40-50$ & 185 & 65.1 \\
\hline \multirow{2}{*}{ Level of education } & $50-60$ & 28 & 9.9 \\
\cline { 2 - 4 } & Secondary & --- & --- \\
\cline { 2 - 4 } & Bachelor Degree & 257 & 90.5 \\
\hline Years of experience in the & MSc or PhD Degree & 27 & 9.5 \\
\cline { 2 - 4 } current position & $2-6$ & 57 & 20.4 \\
\cline { 2 - 4 } & $6-10$ & 84 & 29.6 \\
\hline
\end{tabular}

Descriptive statistics were implemented to attain mean scores, standard deviation, variance and percent of the questionnaire statements which listed in Table (2). The mean score for the overall agreement of menu sustainability practices ranging from 4.05 for Reducing and managing waste to 1.48 for Growing some ingredients.

As shown in Table (2) the mangers of investigated restaurants were aware and committed to implement principles and practices of sustainability in the menus (mean=3.63). The majority of 
the respondents (95.7\%) agreed that there is growing increase of awareness among diners of the importance of sustainability and how their nutrition habits can effect on the environment and increase carbon footprint. Also, $85 \%$ of the managers agreed that customers like innovation and to try something new and more than half of the respondents $(68.4 \%)$ agreed that menu sustainability has become a moral priority. But, nearly half of the respondents $(46.6 \%)$ indicated that their restaurants did not adopt a small menu to make customers' decision-making process easier and approachable. Results also showed that more than half of the investigated restaurants (62.2\%) had not a list of ethical suppliers to choose from. The high level of awareness and commitment among managers due to the level of education and the period of experience spent in the hospitality industry, the results showed a positive correlation between level of education and experience and managers' awareness and commitment to sustainable practices ( $\mathrm{r}=0.57$ and 0.48$)$. These results are consistent with Haleblian and Finkelstein (1993) and Goll and Rasheed (2006) that level of education and experience are important factors effect on the top managers' perspectives and their commitment to environmental practices.

This study found that participants views were neutral regarding the effort in improving their staff awareness of sustainability (mean=2.96). This principle comprised four practices. The high practice included "our chefs are paying attention to how and from whom they are sourcing their ingredients (mean= 4.57)". Two practices had a value lower than three (neither agree nor disagree), the statements were "we are conducting sustainable training about the ingredients that staff uses so they can repeat those stories to customers (mean=2.95)" and "we are training our staff to explain how to plan menu around seasonality and sustainability first (mean=2.72)". Also, only $8.5 \%$ of the restaurants' teams visited local farms periodically, so they can learn about the products they're working with.

One of the key findings of is that the respondents depended on local source, seasonal and organic ingredients in their restaurants $($ mean $=3.66)$. There were seven practices in this principle. The high practices were "we planned our menu to the flow of season, and purchase the fresh seasonal products at its peak periods (mean= 4.75)", "sourcing food locally promotes the local market, shortens supply chains and raises the profile of farmers in the region (mean= 4.11)", "in our restaurant, bread and bakery items baked fresh daily by local bakeries (mean=4.08)", "we are changing our menu monthly to serve the freshest possible produce at its peak (mean= 3.62)","our restaurant support local communities and bring food from nearby suppliers (mean=3.56)" and "our sources of food and ingredients are organic (3.50)". The majority of the managers (89.2\%) did not agree that their dairy products come from milk farmed locally, sustainably and are handstretched in the dairy directly above the restaurant every single day.

Table (2) revealed that the investigated restaurants provided balanced, healthy and nutritious meals (mean= 3.63). The high practices in this principle included the statements, "we cut down sugar, salt and fat, genetic modified ingredients (GM) and some food additives across the menu $($ mean $=4.70)$ ", "we reduced the amount of meat we serve per plate and increased the portions of vegetarian options (mean= 4.42)", "serving more vegetables, fruit, grains, and lesser amounts of animal products helps reduce health risks and greenhouse gases $($ mean $=4.19) "$. The statements" our restaurant provides the customers with option to order half- portion and uses smaller dishes pattern " and "we switched to sustainable fish, free-range poultry, grass-fed beef for an animalwelfare standpoint a human health perspective " had a low mean value, mean=2.09 and 2.05 respectively. According to Sloan et al. (2013) menus should be based on items that are in season and chefs should look for inspiration from the flow of seasons and the fresh products. According to the participants, they are making ongoing effort to reduce and manage waste (mean=4.05). 
They decided that they are printing menus on an eco- paper and recycled paper and using linen napkins in their restaurants instead of paper ones (mean=4.30) and they also are reducing food waste to save not only energy, money, effort, but also natural resources (mean=3.8).

The investigated Restaurants were keen for providing organic and healthy products due to many reasons. Globally, the organic and natural food market is growing at a much faster rate than traditional foods. Factors contributed to this growing included the increasing of global awareness of the importance of organic foods consumption, most notably the improvement in living standards, success lies in advertising by the international organizations and associations working in this field that have succeeded in bringing about real change in the consumption of food and organic beverages, by focusing on the importance of eating organic foods. Egypt needs a law on organic agriculture that includes production or transmission, inspection. A law on organic agriculture and thus the possibility of inspection and control, and provide a fair price for each Product, marketer and consumer. 
International Journal of Heritage, Tourism and Hospitality Vol. (11), No. (1/2), March, 2017

By: Faculty of Tourism and Hotels, Fayoum University

Table2. Menu Sustainability principles and practices

\begin{tabular}{|c|c|c|c|c|c|c|}
\hline \multirow{2}{*}{ Menu Sustainability Principles and Practices } & \multirow[b]{2}{*}{ Mean } & \multirow[b]{2}{*}{ SD } & \multirow[b]{2}{*}{$\mathbf{V}$} & \multicolumn{3}{|c|}{ 5-Point Likert Scale (\%) } \\
\hline & & & & $5+4$ & 3 & $1+2$ \\
\hline A. Management awareness and commitment to sustainable menu & (3.63) & & & & & \\
\hline $\begin{array}{l}\text { 1. Customers are increasingly aware of the importance of sustainability and } \\
\text { thinking differently about their food and nutrition habits. }\end{array}$ & 4.78 & 0.814 & 2.658 & 95.7 & ------- & 4.3 \\
\hline $\begin{array}{l}\text { 2. Customers like innovation and they are more likely to try something } \\
\text { new in a restaurant. }\end{array}$ & 4.62 & 1.036 & 5.057 & 85 & 9.2 & 5.8 \\
\hline 3. Menu sustainability has become a moral priority. & 3.8 & 1.650 & 3.563 & 68.4 & 27.6 & 4 \\
\hline $\begin{array}{l}\text { 4. The move to a sustainable menu is an opportunity for caterers, diners } \\
\text { and community. }\end{array}$ & 3.8 & 1.024 & ------- & 76 & 12 & 12 \\
\hline $\begin{array}{l}\text { 5. Our restaurant provides customers with detailed information about food } \\
\text { production methods, sourcing, calorie and nutrient values, animal welfare, } \\
\text { and environmental effects. }\end{array}$ & 3.43 & 1.3892 & ------- & 54.4 & 17.8 & 27.8 \\
\hline $\begin{array}{l}\text { 6. We adopted small menu to make customers' decision- making process } \\
\text { easier and approachable. }\end{array}$ & 2.89 & 1.287 & ------- & 35.1 & 18.5 & 46.6 \\
\hline 7. Our restaurant has ethical suppliers to choose from. & 2.12 & 1.277 & 2.478 & 17 & 20.8 & 62.2 \\
\hline B. Improving staff awareness of sustainability. & $(2.96)$ & & & & & \\
\hline $\begin{array}{l}\text { 1. Our Chefs are paying attention to how and from whom they are sourcing } \\
\text { their ingredients }\end{array}$ & 4.57 & .587 & 8.614 & 92.4 & .3 & 7.3 \\
\hline $\begin{array}{l}\text { 2. We are conducting sustainable training about the ingredients that staff } \\
\text { uses so they can repeat those stories to customers. }\end{array}$ & 2.95 & 1.449 & -------- & 45.1 & 9.8 & 45.1 \\
\hline $\begin{array}{l}\text { 3. We are training our staff to explain how to plan menu around seasonality } \\
\text { and sustainability first. }\end{array}$ & 2.72 & 1.459 & ------- & 35.1 & 12 & 52.9 \\
\hline $\begin{array}{l}\text { 4. Our teams are visiting local farms periodically so they can learn about } \\
\text { the products they're working with. }\end{array}$ & 1.61 & 1.025 & --------- & 8.5 & 4.5 & 87 \\
\hline C. Depending on local source, seasonal and organic ingredients. & (3.66) & & & & & \\
\hline $\begin{array}{l}\text { 1. We planned our menu to the flow of season, and purchase the fresh } \\
\text { seasonal products at its peak periods. }\end{array}$ & 4.75 & 0.727 & 2.475 & 93.2 & 1.5 & 5.3 \\
\hline $\begin{array}{l}\text { 2. Sourcing food locally promotes the local market, shortens supply chains } \\
\text { and raises the profile of farmers in the region. }\end{array}$ & 4.11 & 0.950 & 5.794 & 76.2 & 6.5 & 17.3 \\
\hline $\begin{array}{l}\text { 3. In our restaurant, Bread and bakery items baked fresh daily by local } \\
\text { bakeries }\end{array}$ & 4.08 & 1.144 & ------- & 75.4 & 9.8 & 14.8 \\
\hline
\end{tabular}


International Journal of Heritage, Tourism and Hospitality Vol. (11), No. (1/2), March, 2017

By: Faculty of Tourism and Hotels, Fayoum University

\begin{tabular}{|c|c|c|c|c|c|c|}
\hline $\begin{array}{l}\text { 4. We are changing our menu monthly to serve the freshest possible } \\
\text { produce at its peak. }\end{array}$ & 3.62 & 1.370 & 2.366 & 59.4 & 10.3 & 30.3 \\
\hline $\begin{array}{l}\text { 5. Our restaurant support local communities and bring food from nearby } \\
\text { suppliers. }\end{array}$ & 3.56 & 1.50 & ------- & 63.4 & 10 & 26.5 \\
\hline 6. Our sources of food and ingredients are organic. & 3.50 & 1.324 & ------- & 63.9 & 5.8 & 30.3 \\
\hline $\begin{array}{l}\text { 7. Our dairy products come from milk farmed locally, sustainably and are } \\
\text { hand-stretched in the dairy directly above the restaurant every single day. }\end{array}$ & 2.00 & .4011 & 3.032 & 9 & 1.8 & 89.2 \\
\hline \multicolumn{7}{|l|}{ D. Serving balanced, healthy and nutritious meals. } \\
\hline $\begin{array}{l}\text { 1. We cut down sugar, salt and fat, genetic modified ingredients (GM) and } \\
\text { some food additives across the menu. }\end{array}$ & 4.70 & 0.992 & 2.732 & 95.7 & 4.3 & ------- \\
\hline $\begin{array}{l}\text { 2. We reduced the amount of meat we serve per plate and increased the } \\
\text { portions of vegetarian options. }\end{array}$ & 4.42 & 1.066 & 7.974 & 83.7 & 3.3 & 13 \\
\hline $\begin{array}{l}\text { 3. serving more vegetables, fruit, grains, and lesser amounts of animal } \\
\text { products to help reducing health risks and greenhouse gases }\end{array}$ & 4.19 & 1.046 & 3.518 & 92 & 3.5 & 4.5 \\
\hline $\begin{array}{l}\text { 4. Our restaurants are using plant oils, canola, soy, peanut, and olive oils } \\
\text { that contain unsaturated fats, as well plant proteins including nuts, seeds, } \\
\text { avocados, and whole grains. }\end{array}$ & 4.19 & 1.046 & 3.518 & 92 & 3.5 & 4.5 \\
\hline $\begin{array}{l}\text { 5. We minimize the use of processed poultry and meat products in our } \\
\text { menu. }\end{array}$ & 3.79 & 1.356 & 4.254 & 97.2 & 1.3 & 1.5 \\
\hline $\begin{array}{l}\text { 6. Our restaurant provides the customers with option to order half- portion } \\
\text { and uses smaller dishes pattern. }\end{array}$ & 2.09 & 0.735 & 2.245 & ------- & 5 & 95 \\
\hline $\begin{array}{l}\text { 7. We switched to sustainable fish, free-range poultry, and grass-fed beef } \\
\text { for an animal-welfare standpoint a human health perspective. }\end{array}$ & 2.05 & 1.306 & ------- & ------- & 39.8 & 60.2 \\
\hline E. Reducing and managing waste. & \multicolumn{6}{|c|}{$(4.05)$} \\
\hline $\begin{array}{l}\text { 1. We are printing menu on an eco- paper and recycled paper and using } \\
\text { linen napkins instead of paper ones. }\end{array}$ & 4.30 & 1.100 & 4.081 & 75.5 & 10.3 & 14 \\
\hline $\begin{array}{l}\text { 2. We Reduce food waste to save the energy, money, effort and natural } \\
\text { resources. }\end{array}$ & 3.8 & 1.650 & 3.563 & 68.4 & 27.6 & 4 \\
\hline F.Growing some ingredients. & \multicolumn{6}{|c|}{$(1.48)$} \\
\hline $\begin{array}{l}\text { 1. We are growing some of our own items in-restaurant by pickling our } \\
\text { own vegetables and making our own salad dressings. }\end{array}$ & 2.12 & 1.277 & 2.748 & 17 & 20.8 & 62.2 \\
\hline $\begin{array}{l}\text { 2. We have interior and exterior window boxes for small plants and herbs } \\
\text { such as chives, mint, rosemary, and parsley. }\end{array}$ & 1.78 & 0.999 & ----- & 27.6 & 7.5 & 64.9 \\
\hline
\end{tabular}


International Journal of Heritage, Tourism and Hospitality Vol. (11), No. (1/2), March, 2017 By: Faculty of Tourism and Hotels, Fayoum University

\begin{tabular}{|c|c|c|c|c|c|c|}
\hline $\begin{array}{l}\text { 3. We started our own green roof and garden for some ingredients such as } \\
\text { carrots, cabbage, beets, and broad beans. }\end{array}$ & 1.73 & 0.846 & ------ & 12.5 & 9.3 & 78.2 \\
\hline $\begin{array}{l}\text { 4. We have our own kitchen garden provides an opportunity for chefs to } \\
\text { learn about how ingredients grow and give the cooks a new appreciation } \\
\text { for those items in their cooking. }\end{array}$ & 1.73 & 0.846 & ------ & 12.5 & 9.3 & 78.2 \\
\hline G. Choosing Fair Trade labeled products. & $(2.80$ & & & & & \\
\hline $\begin{array}{l}\text { 1. Fairly traded products improve quality of life, and help farmers invest in } \\
\text { improving the quality and diversity of their products. }\end{array}$ & 3.88 & 0.876 & ------ & 68.7 & 25.3 & 6 \\
\hline $\begin{array}{l}\text { 2. We are choosing Fair-trade-certified food and beverages to ensure a fair } \\
\text { deal for producers. }\end{array}$ & 1.73 & .4010 & 3.031 & 1.8 & 9 & 89.2 \\
\hline
\end{tabular}

N.B: SD, "Standard Deviation", V, "Variance", 5= "Strongly Agree", 4="Agree", 3="Neither Agree nor Disagree", 2="Disagree", 1="Strongly Disagree" 
The overall mean for the four practices related to the growing of some ingredients in their restaurants was 1.84 (equal to disagree). The statements were in a descending order "We are growing some of our own items in-restaurant by pickling our own vegetables and making our own salad dressings (mean= 2.12)", "We have interior and exterior window boxes for small plants and herbs such as chives, mint, rosemary, and parsley (mean=1.78)". The statements "We started our own green roof and garden for some ingredients such as carrots, cabbage, beets, and broad beans " and "We have our own kitchen garden provides an opportunity for chefs to learn about how ingredients grow and give the cooks a new appreciation for those items in their cooking had the same value (mean=1.73). These results confirmed and agreed with other previous authors such as Sloan et al. (2013) and Dorsey, (2016).

The results showed that the mangers were neutral regarding the principles of choosing Fair-trade labeled products $($ mean $=2.80)$. The respondents were convinced that fairly traded products improve quality of life, and help farmers invest in improving the quality and diversity of their products (mean $=3.88$ ), while, they were not choosing Fair-trade-certified food and beverages to ensure a fair deal for producers (mean=1.73). This could be for many reasons; these products are often not readily available or clearly specified and the reliability of the source as reported by Sloan et al. (2013).

\section{Conclusion and recommentaions}

The current paper focuses on the concept of sustainable menu which can be defined as a way of constructing a menu that ultimately promotes the continuous well-being of ourselves and our planet and considering ecological, environmental, and ethical aspects (Dorsey, 2016).

Previous research showed increasing demand among diners to consider sustainability principles and practices in constructing menu such as Sloan et al. (2013) and Dorsey, (2016).

The findings in this research have highlighted that the investigated restaurants depended on seasonally, locally sourced, organically grown ingredients. They planned their menu to the flow of nature, purchased food at its peak supply, bought bread and bakery items baked fresh daily by local bakeries and changed menu monthly to serve the freshest possible produce at its peak. But the majority of the respondents did not agree that their dairy products come from milk farmed locally, sustainably and are hand-stretched in the dairy directly above the restaurant every single day. The results also revealed that the respondents offered a balanced, healthy and nutritious menu. They cut down sugar, salt and fat, genetic modified ingredients (GM) and some food additives across the menu, reduced the amount of meat per plate and increased the portions of vegetarian options and provided more vegetables, fruit, whole grains, reduced amounts of animal products and minimized the use of processed poultry and meat products in their menu. But they did not; provide the customers with option to order half- portion and use smaller dishes pattern and switch to sustainable fish, free-range poultry, and grass-fed beef.

The results and analysis of the study have shown that the studied restaurants made an effort in reducing and managing waste, as they printed their menus on an eco- paper and recycled paper and used linen napkins in their restaurants instead of paper ones. The results also showed that the restaurants need to take in account growing some of their ingredients. The majority of examined restaurants did not; grow some of their own items in-restaurant by pickling vegetables and make their own salad dressings, have interior and exterior window boxes for small plants and herbs such as chives, mint, rosemary, and parsley, own green roof and garden for some ingredients such as carrots, cabbage, beets, and broad beans and own kitchen garden provides an opportunity 
for chefs to learn about how ingredients grow and give the cooks a new appreciation for those items in their cooking.

In relation to choosing Fair-trade labeled products, the majority of the respondents considered fairly traded products are vital in improving quality of life and helping farmers to invest in improving the quality and diversity of their products. But, they did not choose Fair-tradecertified food and beverages products when constructing their menus. Regarding the sustainability training programs, more than half of the respondents indicated that they did not; conduct sustainable training about the ingredients that staff uses so they can repeat those stories to customers and provide staff training to explain how to plan menu around seasonality and sustainability first. The results also showed that the majority of investigated restaurants' teams did not visit local farms periodically to learn more about the products they're working with.

The current study has some certain limitations. First, this study focused only on general managers and assistant general managers' views and specific area (Greater Cairo). Secondly, this study considers only fine dining restaurants in Egypt; a reasonable inquiry is whether the results would be the same in other operations of food service sector, e.g. fast food, ethnic or specialty restaurants. It would be interesting for future studies to compare managers' views from other food service operations with fine dining restaurants. It is also suggested that researchers could investigate the customers' attitude and motives towards choosing sustainable food.

\section{References}

Albin, B. (2012). Motivation for consumers participating in a sustainable food System. An undergraduate thesis present to the Faculty of The Environmental Studies Program in Partial Fulfillment of Requirements for the Degree of Bachelor of Arts, university of NebraskaLincoln.

Bohdanowicz, P. \& Martinac, I. (2003). Attitudes towards sustainability in chain hotels - Results of a European survey, Conference Proceedings, CIB 2003 International Conference on smart and sustainable built environment, Brisbane.

Bohdanowicz, P. (2005). European hoteliers' environmental attitudes: Greening the business. Cornell Hotel and Restaurant Administration Quarterly, 46, 188-204.

Brown, C. \& Miller, S. (2008). The impacts of local markets: a review of research on farmer's choices in the United States. Environmental Science \& Technology, 42(10), 3508-13. Retrieved from http://www.ncbi.nlm.nih.gov/pubmed/18546681.

Bukhari, K.S., Bhati, M.I., Awan, H.M. \& Wahid, A. (2000). Strengthening the Social 'in Sustainable Development: Finding the Impact of Social Sustainability in Business Performance of Hospitality Sector of Pakistan, retrieved March 2, 2017, from http://cdn.intechopen.com/pdfs/37638/InTech.

Business \& the Environment. (2008). Serving up a green menu. Green Restaurant Association, 19(1), 1-4.

Choi, G. \& Parsa, H. G. (2006) .Green practices II: Measuring restaurant managers' psychological attributes and their willingness to charge for the green practices. Journal of Foodservice Business Research, 9 (4), $41-63$.

Choi, G. \& Parsa, H. G. (2009). Consumers' environmental concerns and behaviors in the lodging industry: A comparison between Greece and the United States. Journal of Quality Assurance in Hospitality \& Tourism, 10, $93-112$. 
Chou, C. J., Chen, K. S., \& Wang, Y. Y. (2012). Green practices in the restaurant industry from an innovation adoption perspective: Evidence from Taiwan. International Journal of Hospitality Management, 31, 703-711.

DeWeerdt, S. (2015). Is local food better? Retrieved August 13, 2016, from http://www. worldwatch.org/node/6064.

DiPietro, R.B.\&Campbell, J. (2014). The influence of service scape and local food attributes on pleasure and revisit intention in an upscale-casual dining restaurant. FIU Hospitality Review,31(4), 1-20.

Dodds, R. \& Joppe, M. (2005). CSR in the Tourism Industry? The Status and Potential for Certification, Codes of Conduct and Guidelines, IFC/World Bank, Washington, retrieved April 2, 2016 from http://siteresources.worldbank.org/INTEXPCOMNET/Resources/CSR in tourism- 2005 .pdf.

Dorsey, J. (2016). 5 Tips for Constructing a Sustainable Restaurant Menu. Retired April 2, 2017, from http://www.jennydorsey.co/blog/date/2014-03.

Durbin, N. (2016). 7 Ways to Create a Sustainable Menu. Retired April 2, 2017, from https://restaurantsuccess.touchbistro.com/touchbistro-blog/7-ways-to-create asustainable menu.

Dutta, K., Umashankar, V., Choi, G. \& Parsa, H. G. (2008). A comparative study of consumers' green practice orientation in India and the United States: A study from the restaurant industry. Journal of Food service Business Research, 11 (3), 269 - 285.

Egypt Fair-trade organization (EFO), (2017). Official Facebook page. Retrieved March 4, 2017, from https://www.facebook.com/rsrc.php/v3/yX/r/3-URv4CDjzM.css

Egyptian Tourist Chamber (ETC), (2015). Chamber of Tourist Establishments guide.

Enz, C. A. \& Siguaw, A. (1999). Best hotel environmental practices. Cornell Hotel \& Restaurant Administration Quarterly,40 (5), 72 - 77.

Erdogan, N. \& Baris, E. (2007). Environmental protection programs and conservation practices of hotels in Ankara, Turkey, Tourism Management, 28 (2), 604-614.

Font, X. (2002). Environmental certification in tourism and hospitality: progress, process and prospects, Tourism Management, 23(3), 197-205.

Food Standards Agency -fair-trade. (2015). available at: https://www.food.gov.uk/.

Gay, L. R., \& Diehl, P. L. (1992). Research Methods for Business and Management. New York: Maxwell Macmillan International.

Goll, I., \& Rasheed, A. A. (2005). The relationships between top management demographic characteristic, rational decision making, environmental munificence, and firm performance. Organization Studies, 26, 999-1023.

Goodman, A. (2000). Implementing sustainability in service operations at Scandic hotels. Interfaces, 30 (3), $202-214$.

Haleblian, J. Finkelstein, S. (1993). Top management team size, CEO dominance and firm performance: The moderating roles of environmental turbulence and discretion. Academy of Management Journal, 36(4), 844-863.

Halperin, M. (2013). Restaurants create sustainable menus. Quick Service Magazine, Retired April 2, 2017, from https://www.qsrmagazine.com/marc-halperin/menu-conscience.

Herrero, M., Thornton, P.K., Notenbaert, A.M., Wood, S., Msangi, S., Freeman, H.A. \&Bossio, D., (2010). Smart investments in sustainable food production: revisiting mixed croplivestock systems.

Horrigan, L., Lawrence, R. S., \& Walker, P. (2002). How sustainable agriculture can address the environmental and human health harms of industrial agriculture. Environmental health perspectives, 110(5), 445. 
Jayawardena, C., Jayawardena, C., Pollard, A., Chort, V., Choi, C. \& Kibicho, W. (2013). Trends and sustainability in the Canadian tourism and hospitality industry, Worldwide Hospitality and Tourism Themes, 5(2), 132-150.

Kasimu, A., Zaiton, S. \& Hassan, H. (2012). Hotels Involvement in Sustainable Tourism Practices in Klang Valley, Malaysia, retrieved March 10, 2017, from http://econ.upm.edu.my/ijem/vol6no1/bab02.pdf.

Laggan, S. (2015). What makes a sustainable menu?. Food ethics, retired April 2, 2017, from http://sustainablefoodtrust.org/articles/?category=food-ethics.

Leviten-Reid, C. \& Zepeda, L. (2004). Consumers' views on local food. Journal of Food Distribution Research, 35(3) 1-6.

Line, N. D., \& Runyan, R. D. (2012). Hospitality marketing research: Recent trends and future directions. International Journal of Hospitality Management, 31, 477-488.

Magnusson, M., (2008). Choice of organic foods is related to perceived consequences for human health and to environmentally friendly behavior. Appetite, 40 (2), 109-117.

Manaktola, K. \& Jauhari, V. (2007). Exploring consumer attitude and behavior towards green practices in the lodging industry in India. International Journal of Contemporary Hospitality Management, 19 (5), 364 - 377.

Marlow, J. (2009). Diet and the environment: does what you eat matter? The American Journal of Clinical Nutrition, 89, 1699S-16703S.

McCullum, C. (2004). Using sustainable agriculture to improve human nutrition and health. Journal of Community Nutrition, 6 (1), 18-25.

McMichael, A. J., Powles, J. W., Butler, C. D., \& Uauy, R. (2007). Food, livestock production energy, climate change, and health. Lancet, 370(9594), 1253-63. doi:10.1016/S01406736(07)61256-2

Munjal, S., Sharma, S. \& Menon, P. (2016).Moving towards "Slow Food", the new frontier of culinary innovation in India: The Vedatya experience. Worldwide Hospitality and Tourism Themes, 8(4), 444-460.

Namkung, Y. \&Jang, S. (2017). Are Consumers willing to pay more for Green Practices at Restaurants?. Journal of Hospitality \& Tourism Research, 41(3), 329-356

Nielsen, B. (2004). A guide to creating environmentally sustainable restaurants and kitchens. Sharon, USA: Green Restaurant Association.

Pollan, M. (2001, May 13). Naturally. New York Times. New York. Retrieved from http://www.nytimes.com/2001/05/13/magazine/naturally.html.

Raymond, B.P.L. (2016). Implementation of sustainable development practices in the hospitality industry: a case study of five Canadian hotels", International Journal of Contemporary Hospitality Management, 28(3), p. 60- 88.

Rose, N., Serrano, E., Hosig, K., Haas, C., Reaves, D., \& Nickols-Richardson, S. M. (2008). The 100-mile diet: a community approach to promote sustainable food systems impacts dietary quality. Journal of Hunger \& Environmental Nutrition, 3(2-3), 270-285.

Schneider, M. \& Francis, C. (2005). Marketing locally produced foods: consumer and farmer. Opinions in Washington County, Nebraska. Renewable Agriculture and Food System, 20(4), 252-260.

Schubert, F., Kandampully, J., Solnet,D. \& Kralj, A. (2010). Exploring consumer perceptions of green restaurants in the US. Tourism and Hospitality Research, 10(4), 286-300.

Seyfang, G. (2006). Ecological citizenship and sustainable consumption: examining local organic. Food networks. Journal of Rural Studies, 22, 383-395. 
Sloan, P., Legrand, W. \& Chen, J.S. (2013). Sustainability in the Hospitality Industry: Principles of Sustainable Operations, Rutledge, retrieved February 10, 2017, from http://books.google.co.uk/books?hl=en\&lr=\&id=DzvFWbOsiv0C\&oi=fnd\&pg=PP2\&dq=su stainability+in+the+hospitality+industry\&ots=t4yeaiue1v\&sig=MEkDbN03_jAX3gE3Pr4I AHPhQKU.

Sloan, P., Legrand, W., Tooman, H. \& Fendt, J. (2009). Best practices in sustainability: German and Estonian hotels, Advances in Hospitality and Leisure, 5, 89-107.

Sloan, P.; Legrand, W. \& Chen, J.S. (2003). Assessing Hoteliers' Awareness and Perception of Environmental Initiatives, Conference Proceedings, EuroCHRIE Congress, Bad Honnef, Germany.

Solomon, M. R.; Barnossy, G.; Askegaard, S. \& Hogg, M. K. (2010). Consumer Behavior: A European Perspective ( ${ }^{\text {th }}$ ed.). Essex, England: Pearson Education Limited.

SUSTAIN (2009). What is sustainable food, available at: www.sustainweb.org/page. php?id1/4402.

The Culinary Institute of America, (2015). Principles of Healthy, Sustainable Menus. Retired April 2, 2017, from http://www.menusofchange.org/principles-resources/moc-principles/\#" id="menu-icon.

Trip Advisor. (2010). TripAdvisor travelers keen on going green. Retrieved April 15, 2016 from http://www.tripadvisor.com/PressCenter-i134-c1-Press_Releases.html.

Trivette, S.A. (2012).Farm-to-fork: Understanding locally-oriented farm to vendor food systems: Access, boundaries, and power-relations. PhD Thesis. University of Massachusetts, Amherst, MA.

Tzschentke, N.A., Kirk, D. \& Lynch, P.A. (2008). Going green: Decisional factors in small hospitality operations", International Journal of Hospitality Management, 27(1), 126-133.

Van Rheede, A. \& Blomme, R.J. (2012). Sustainable Practices in Hospitality: A Research Framework", Advances in Hospitality and Leisure, 8, 257-271.

Vermeir, I. \& Verbeke, W. (2006). Sustainable food consumption: Exploring the consumer 'attitude-behavioral intention' gap, Journal of Agricultural and Environmental Ethics, 19(2), 169-194.

Vieregge, M., Scanlon, N. \& Huss, J. (2007).Marketing locally grown food products in globally branded restaurants: Do customers care? Journal of Food Service Business Research, 10 (2), $67-82$.

Weber, C. L., \& Matthews, H. S. (2008). Food-miles and the relative climate impacts of food choices in the United States. Environmental Science \& Technology, 42(10), 350813.Retrieved March 20, 2017, from http://www.ncbi.nlm.nih.gov/pubmed/18546681

Webster, K. (2004). Environmental Management in the Hospitality Industry: A Guide for Students and Managers, Cengage Learning EMEA, retrieved March 10, 2017, from https://books.google.co.uk/books?hl=en\&lr=\&id=eCewh284lkwC\&oi=fnd\&pg=PR7\&dq= Webster+(2000+environmental\&ots=BrFqIzxtNG\&sig=eC6a4ukeERUa5-DpYHqf6lTcI8Y.

Wilkins, H., Merrilees, B. \& Herington, C. (2007). Towards an understanding of total service quality in hotels, International Journal of Hospitality Management, 26 (4), 840-853.

Willard, B. (2005). The Next Sustainability Wave: Building Boardroom Buy---in. Gabriola Island, British Columbia, Canada: New Society Publishers.

Zhang, J.J., Joglekar, N.R. \& Verma, R. (2012). Exploring resource efficiency benchmarks for environmental sustainability in hotels, Cornell Hospitality Quarterly, 53(3), 229-241. 